African Crop Science Journal by African Crop Science Society is licensed under a Creative Commons Attribution 3.0 Uganda License. Based on a work at www.ajol.info/ and www.bioline.org.br/cs DOI: http://dx.doi.org/10.4314/acsj.v26i1.7

\title{
TRENCH LAYERING USING INDOLE-3-BUTYRIC ACID AND LOCAL ORGANIC SUBSTRATE MIXTURES TO ENHANCE ROOTING AND SURVIVAL OF APPLE ROOTSTOCKS
}

\author{
R. AGABA, F. BABWETEERA ${ }^{1}$, S. BALABA TUMWEBAZE ${ }^{1}$, M. TWEHEYO \\ and N. TURYAHABWE ${ }^{2}$
}

Department of Agricultural Production, Makerere University, P. O. Box 7062, Kampala, Uganda ${ }^{1}$ Department of Forestry, Bio-diversity and Tourism, Makerere University, P. O. Box 7062, Kampala, Uganda

${ }^{2}$ Department of Extension and Innovation Studies, Makerere University, P. O. Box 7062, Kampala, Uganda Corresponding author: rondessblessed@gmail.com

(Received 4 October, 2017; accepted 12 February, 2018)

\begin{abstract}
Apples (Malus domestica) were introduced to enhance nutrition and improve livelihoods of famers in highlands of Uganda. However, adoption and commercialisation of apples is largely constrained by low quality rootstocks due to poor rooting and low survivability. This study determined the effect of organic substrate mixtures (OSM) and indole-3-butyric acid (IBA) on rooting, sprouting and survival characteristics of apple rootstocks propagated by trench layering. Four apple rootstock varieties (M106, M109, MM793 and bitten-felder) were planted in OSM (Site soil as control, TsaOm and TsdOm) then treated with IBA concentrations (IBA-0 ppm, IBA-4000 ppm and IBA-8000 ppm) in a factorial randomised block design with three replications. Results showed significant $(\mathrm{P}<0.001)$ variability among rootstocks for all characters. OSM significantly $(\mathrm{P}<0.01)$ increased rooting, root numbers and root length while IBA significantly $(\mathrm{P}<0.01)$ increased all traits, except rooting. The highest rooting $(46.7 \%)$, root numbers $(23.1)$ and root length $(14.9 \mathrm{~cm})$, and sprout length $(59.5 \mathrm{~cm})$ were obtained in bitten felder under TsaOm + IBA-4000ppm, TsaOm, and TsdOm, respectively. For M106, maximum rooting (28.1\%) and root numbers (22.3) were obtained under TsaOm + IBA-8000ppm while root $(14.3 \mathrm{~cm})$ and sprout $(35.2 \mathrm{~cm})$ lengths under TsdOm. TsaOm gave the highest root numbers $(14.2)$, root $(12.8 \mathrm{~cm})$ and sprout $(30.7 \mathrm{~cm})$ lengths in M109 likewise root $(7.8 \mathrm{~cm})$ and sprout (38.3 cm) lengths in MM793. Logistic regression revealed that rooting, sprout length, and IBA-4000ppm significantly $(\mathrm{P}<0.01)$ increased survival of apple rootstocks. The highest survival rates in bitten felder and M106 were 52.4\% and 51.7\% under TsdOm + IBA-4000 ppm and TsdOm + IBA-8000 ppm respectively; likewise 49.5\% in M109 and 51.7\% in MM793 both treated with IBA-8000 ppm. The results demonstrate that trench layering with OSM and IBA improves rooting and survival of apple rootstocks which might improve farmers' access to quality apple planting material.
\end{abstract}

Key Words: IBA, Malus domestica, rootstocks, trench propagation

\section{RÉSUMÉ}

Les pommes (Malus domestica) étaient introduites pour renforcer la nutrition et améliorer le niveau de vie des producteurs dans les régions montagneuses d'Ouganda. Toutefois, l'adoption et la commercialisation des pommes sont largement limitées par la faible qualité des porte-greffes à cause du pauvre enracinement et la faible capacité de survie. Cette étude visait à déterminer l'effet des mélanges du substrat organique (OSM) et l'acide indole-3butyrique (IBA) sur l'enracinement, la germination et les caractéristiques de survie des porte-greffes de la pomme 
propagée par le marcottage de tranchée. Quatre portes greffes des variétés de pomme (M106, M109, MM793 et bitten-felder) étaient plantées dans l'OSM (site de sol servant de contrôle, TsaOm et TSdOm) et traitée avec différentes concentrations de l'IBA (IBA-0 ppm, IBA-4000 ppm et IBA-8000 ppm) dans un design factoriel à blocks complètement aléatoires avec trois réplications. Les résultats ont montré de variabilité significative $(\mathrm{P}<0,001)$ entre les porte-greffes des variétés pour tous les caractères. OSM significativement $(\mathrm{P}<0.01)$ a fait accroître l'enracinement, le nombre de racines et la longueur de la racine; alors que IBA a augmenté significativement $(\mathrm{P}<0.001)$ tous les traits, sauf l'enracinement. Les plus grandes valeurs des caractères à savoir ; l'enracinement $(46,7 \%)$, le nombre de racines $(23,1)$, la longueur des racines $(14,9 \mathrm{~cm})$, et la longueur des pousses $(59,5 \mathrm{~cm})$ étaient obtenues sur bitten felder sous TsaOm + IBA-4000ppm, TsaOm, et TsdOm, respectivement. Pour M106, les valeurs maximales de l'enracinement $(28,1 \%)$ et de nombre de racines (22.3) étaient obtenues sous TsaOm + IBA-8000ppm alors que les valeurs maximales de la longueur des racines $(14,3 \mathrm{~cm})$ et des pousses $(35,2$ $\mathrm{cm})$ sous TsdOM. TsaOm ont donné le plus grand nombre de racines $(14,2)$, la plus grande longueur des racines $(12,8 \mathrm{~cm})$ et de pousses $(30,7 \mathrm{~cm})$ dans M109 pareillement à la longueur des racines $(7,8 \mathrm{~cm})$ et de pousses $(38,3$ $\mathrm{cm})$ dans MM793. La régression logistique a révélé que l'enracinement, la longueur de la pousse et IBA-400ppm ont augmenté significativement $(\mathrm{P}<0,01)$ la survie des porte-greffes de la pomme. Les plus forts taux de survies sur le bitten felder et M106 étaient 52,4\% et 51,7\% sous TsdOm+IBA-4000 ppm et TsdOm+IBA-8000 ppm, respectivement ; de même 49,5\% ont été obtenus sur M109 et 51,7\% sur MM793 tous traités avec IBA-8000 ppm. Les résultats ont démontré que le marcottage de tranchée avec OSM et IBA améliore l'racinement et la survie des porte-greffes qui pourrait améliorer l'accès des producteurs à des matériels de plantation de pomme de qualité.

Mots Clés: IBA, Malus domestica, porte-greffe, propagation par tranchée

\section{INTRODUCTION}

The cultivated apple (Malus domestica) has a central Asian origin and a large secondary contribution from the European crabapple (Cornille et al., 2014), yet are the most important temperate fruit trees globally (Sharma et al., 2013; Noormohammadi et al., 2015). Apple is the second most significant cultivated fruit tree worldwide, after the Banana (Akbari et al., 2015). Apple accounts for about $50 \%$ of the world's deciduous fruit tree production and has become a gainful cash crop for tropical farming systems (Kashyap and Guleria, 2015). According to Liu et al. (2016), consumption of apples provide health benefits because its fruits are a rich source of vitamins $\mathrm{A}, \mathrm{B}$ and $\mathrm{C}$; proteins, carbohydrates, minerals, fibre and phenolic compounds vital for wound healing.

Apples were introduced into the tropics mainly through the use of clonal and seedling rootstocks, that are adapted to the edaphic and agronomic conditions of tropical farming systems (Griesbach, 2007). Since 2004, apple growing has been promoted in Uganda to diversify highland farming systems, augment family nutrition, alleviate poverty and improve house hold incomes and livelihoods, and mitigate land degradation by offering perennial orchards that minimise seasonal cultivation and associated soil erosion (Raussen, 2001; Chemining'wa et al., 2005; Musana et al., 2006). Growing of apples was mainly introduced into the highlands areas of Kigezi, Mt. Rwenzori and Mt. Elgon to improve access to fruit based nutrients among small-scale farmers (ICRAF, 2003).

Four apple varieties of Anna, Golden dorset, Rome beauty and Winter banana were introduced for research at Kachekano Zonal Agricultural Research and Development Institute (KAZARDI), and evaluated at three sub-stations viz., Bugongi, Kalengyere and Kachwekano in 2009 (Namirembe et al., 2006). Subsequently, the two best performing varieties, Anna and Golden dorset, were taken for on-farm trials. Yields of up to 50 fruits per tree were obtained as the first fruits under minimal farmer management (Turyomurugyendo et al., 2004). As reported by Ntakyo et al. (2013), apple growing has 
increasingly become a gainful cash crop for small holder farmers in South-Western highlands of Uganda.

The main bottleneck is that access to quality apple planting material in Uganda is limited and seedlings are expensive for most farmers due to dependence on seed imports and inefficient propagation methods (Turyomurugyendo et al., 2004; Ntakyo et al., 2013). Poor access to quality planting materials constitutes a major constraint to the scaling up of apple production in Uganda. Despite the importation of various apple rootstock varieties that were adapted to tropical highlands, viz. bittern felder, M11, M106, M109, MM793, M25 and M7, multiplication efforts especially by trench layering are curtailed by long nursery gestation, poor rooting and low survival of rootstocks (Agaba, 2011). As noted by Crabtree (2004), trench layering is a most convenient and cheap method for propagation of difficult-to-root plants such as apples. But apple seedlings produced by trench layering in Kigezi highlands are usually sold after one to three years in the nursery, causing loss of time and escalating costs (Khatik and Sharma, 2013). According to Ntakyo et al. (2013), the high cost of planting materials constitutes a major constraint to apple production in Uganda, making seedlings largely unaffordable to small holder farmers. Rootstocks are widely used to control growth and accelerate maturity of apples (Katuuramu, 2012).

Rapid propagation of apple rootstocks through integration of OSM and IBA in trench layering could improve supply of affordable and quality apple planting materials and encourage farmers in the tropical highlands to venture into commercial apple cultivation. This study was thus conducted to investigate the effect of organic substrate mixtures (OSM) and indole-3-butyric acid (IBA) treatments on rooting, sprouting and survival characteristics of apple rootstocks propagated by trench layering.

\section{MATERIALS AND METHODS}

Experimental site and germplasm. The layering and acclimatisation experiments were conducted at the trench layering gardens at Bugongi substation of Kachekano Zonal Agricultural Research and Development Institute (KAZARDI) in April 2011. The site is located in the South Western highlands of Uganda; an area characterised by tropical montane eco geographical zones and high altitude of about 2220 masl. The area receives a bimodal rainfall of approximately $1319 \mathrm{~mm}$ per year; a mean annual temperature of $18^{\circ} \mathrm{C}$ and has sandy clay roam soils with an average $\mathrm{pH}$ 5.8-6.2.

The germplasm consisted of four apple rootstock varieties namely, bitten felder, M106, M109 and MM793 selected from the trench layering mother garden at Bugongi-KAZARDI. These rootstocks were selected because they constituted the most promising genotypes for production of adapted and quality apple seedlings suitable for agro ecological conditions of South Western Uganda (Agaba, 2011).

Preparation and application of organic substrates and IBA treatments. Rooting media was made by mixing three organic substrates namely top forest soil, sand and organic manure in a ratio of $3: 1: 1$ to obtain two substrate mixtures of top forest soil + sand + organic manure (TsaOm), Top forest soil + sawdust + organic manure (TsdOm). Then indole-3-butyric acid (IBA) was dissolved using distilled water to obtain two treatment concentrations namely, $4000 \mathrm{ppm}$ and $8000 \mathrm{ppm}$. These IBA concentrations were used following recommendations of Srivastava et al. (2006) that identified such high concentrations as suitable for propagating difficult-to- root fruit trees such as apples. The site soil with no application of organic substrates and IBA hormones was considered as the control. 
Six months old apple rootstocks consisting of bitten felder, M106, M109 and MM793 in the trench layering mother gardens at BugongiKAZARDI were selected, defoliated, bent and pegged into a trench (Fig. 1). The trenches were then covered with organic substrate mixtures (TsaOm and TsdOm) and site soil as the control then left to sprout and grow for three months. After three months, the organic substrates were removed and the sprouts were girdled by cutting a $1 \mathrm{~cm}$ ring around the sprout base, using a stainless steel knife. Then IBA treatments namely, 0 (control), 4000ppm, and $8000 \mathrm{ppm}$ were applied to the girdle, using a paint brush (Fig. 1).

The treatments were applied in a factorial randomised block design, with three plot replications, consisting of nine treatments (Table 1). Treatments consisted of $4 \times 3 \times 3$ factorial structure involving four apple rootstock genotypes, three levels of hormone
(IBA) concentrations $(0,4000$ and 8000) ppm and three organic substrate mixtures (site soils, TsaOm and TsdOm).

Harvesting and acclimatisation. After application of IBA, sprouts were covered with the organic substrate mixtures until harvesting at 6 weeks after hormone application. Individual sprouts were then harvested from the mother rootstocks in the layering nursery, defoliated, root pruned and potted in polythene bags filled with mixtures of top forest soil, organic matter (decomposed cow dung) and sand (ratios: $3-1-1 \mathrm{v} / \mathrm{v}$ ). The potted rootstocks were transferred to the acclimatisation nursery beds covered by $70 \%$ solar radiation nets, where survivability assessment was done for a period of 8 weeks.

Data collection. Data were recorded for rooting percentage, root numbers ( average

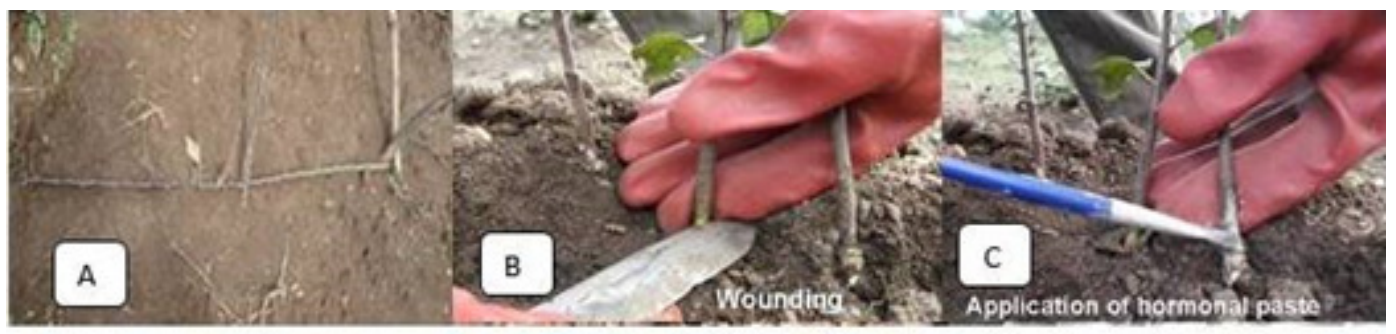

Figure 1. Defoliated apple rootstocks pegged into a trench (A), girdling of three months old sprouts (B) and application of IBA hormone on sprouts (C) in the trench layering nursery at Bugongi - KAZARDI in SouthWestern Uganda.

TABLE 1. Treatment combinations of OSM and IBA hormone concentrations as used in the experiment to propagate apple rootstocks under trench layering at Bugongi -KAZARDI

\begin{tabular}{ll}
\hline Treatment no. & OSM combined with different levels of IBA concentrations \\
\hline 1. & Control (site soil) without OSM and no IBA (IBA-0 ppm ) \\
2. & Control (site soil) combined with IBA-4000ppm \\
3. & Control (site soil) combined with IBA-8000ppm \\
4. & Top forest soil+ sand+ organic manure (TsaOm) combined without IBA (IBA-0 ppm) \\
5. & Top forest soil+ sawdust+ organic manure (TsdOm) combined without IBA (IBA-0 ppm) \\
6. & Top forest soil+ sand+ organic manure (TsaOm) combined with IBA-4000ppm \\
7. & Top forest soil+ sawdust+ organic manure (TsdOm) combined with IBA-4000ppm \\
8. & Top forest soil+ sand+ organic manure (TsaOm) combined with IBA-8000ppm \\
9. & Top forest soil+ sawdust+ organic manure (TsdOm) combined with IBA-8000ppm \\
\hline
\end{tabular}


count of roots per variety), root length, sprout length and survival rates for each of the four apple rootstock varieties prior to root pruning and potting. Rooting percentage was determined as a fraction of rooted rootstocks to total rootstocks harvested from each mother rootstock for each treatment following procedures described by Hartmann et al. (1997). Root length was determined by measuring the length of three roots per individual rootstock and the average was recorded. The survival rates were determined by counting number of rootstocks alive 8 weeks after potting and transferring rootstocks to the acclimatisation nursery beds.

Data analysis. The collected data were subjected to analysis of variance using MINITAB statistical software, Version 14 and the difference between means was compared using the average least significant difference. Logistic regression analysis was undertaken to test the effect of different factors (root numbers, root length, sprout length, IBA concentration and organic substrate mixtures) on the survival rates of the different rootstock varieties during the acclimatisation stage. Multicolinearity test was performed, to assess the assumption that the predicator variables are independent of each other in influencing survivability of the apple rootstocks.

\section{RESULTS}

Analysis of variance. The combined analysis of variance revealed significant $(\mathrm{P}<0.001)$ and non-significant $(\mathrm{P}>0.05)$ differences in response of the four rootstock varieties (Bitten felder, M106, M109 and MM793) to IBA and OSM treatments for all the traits viz., rooting characteristics, sprout length and survival rates (Table 2).

\section{Effect of OSM and IBA on rooting} percentages. The use of OSM in trench layering had significant effect $(\mathrm{P}<0.01)$ on rooting percentage, root numbers, root length and sprout length of rootstocks (Table 2). From the results of multiple comparisons, the best response in rooting percentage was obtained in M109 treated with TsdOm (37.4\%) but $\mathrm{TsaOm}$ resulted in lower rooting percentage of $25.8 \%$ compared to $28.4 \%$ under control conditions (Table 3 ). Rooting percentages increased by two times in rootstock MM793 when treated with TsaOm and TsdOm to $15.2 \%$ and $13.0 \%$ respectively as compared to the control conditions (site soil) where rooting was at $6.0 \%$ (Table 3). In M106 rootstock, TsaOm increased rooting percentage from $19.4 \%$ under control conditions to $21.9 \%$ but reduced to $14.8 \%$ under TsdOm.

TABLE 2. Estimates of mean squares due to OSM and IBA treatment effects on root traits, sprout length and survival of apple rootstocks propagated under trench layering

\begin{tabular}{lcccccc}
\hline Source of variation & Df & \multicolumn{5}{c}{ Mean squares } \\
\cline { 3 - 6 } & & $\begin{array}{c}\text { Rooting } \\
\text { percentage }\end{array}$ & $\begin{array}{c}\text { Number of } \\
\text { roots }\end{array}$ & $\begin{array}{c}\text { Root } \\
\text { length }\end{array}$ & $\begin{array}{c}\text { Sprout } \\
\text { length }\end{array}$ & $\begin{array}{c}\text { Survival } \\
\text { rates }\end{array}$ \\
\hline Variety & 3 & $45.33^{* * *}$ & $54.25^{* * *}$ & $27.08^{* * *}$ & $61.17 * * *$ & $17.37 * * *$ \\
IBA & 2 & 0.71 & $5.02^{* * *}$ & $13.85^{* * *}$ & $3.11^{* * *}$ & $2.53^{* *}$ \\
OSM & 2 & $4.18^{*}$ & $4.63^{* * *}$ & $2.38^{* *}$ & $1.32^{* * *}$ & 0.72 \\
Variety*IBA & 6 & $1.64^{* *}$ & 0.29 & 0.52 & 0.57 & $2.98^{* *}$ \\
Variety*OSM & 6 & $5.46^{* * *}$ & $3.08^{* * *}$ & 0.91 & 0.37 & 1.57 \\
IBA*OSM & 4 & $8.0^{* * *}$ & $2.48^{* * *}$ & $6.22^{* * *}$ & $0.72^{* *}$ & $2.3 * * *$ \\
Variety*IBA*OSM & 12 & $3.88^{* * *}$ & $4.02^{* * *}$ & $3.63 * * *$ & $0.63 *$ & 1.15 \\
\hline
\end{tabular}

IBA = indole-3-butyric acid; OSM = organic substrate mixtures; $* * *$ and $* * *=$ significant at $0.05,0.01$ and $<0.001 \alpha$-level, respectively 
TABLE 3. Effects of OSM, IBA on the rooting, sprout length and survival rates of apple rootstocks propagated under trench layering at Bugongi-KAZARDI, South Western Uganda

\begin{tabular}{|c|c|c|c|c|c|c|}
\hline $\begin{array}{l}\text { Rootstock } \\
\text { Variety }\end{array}$ & Treatments & $\begin{array}{l}\text { Rooting } \\
\text { rate }(\%)\end{array}$ & $\begin{array}{c}\text { Root } \\
\text { numbers }\end{array}$ & $\begin{array}{c}\text { Root } \\
\text { length }(\mathrm{cm})\end{array}$ & $\begin{array}{c}\text { Sprout } \\
\text { lentgh }(\mathrm{cm})\end{array}$ & $\begin{array}{l}\text { Survival } \\
\text { rate }(\%)\end{array}$ \\
\hline \multirow[t]{9}{*}{$\mathrm{BF}$} & Control & $46.3^{\text {ag,** }}$ & $5.52^{\mathrm{bc}}$ & $11.3^{\mathrm{b}}$ & $54.8^{\mathrm{abc}}$ & $28.7^{\mathrm{abc}}$ \\
\hline & TsaOm & $37.1^{\mathrm{b}}$ & $23.1^{\mathrm{a}}$ & $14.9^{\mathrm{b}}$ & $56.2^{\mathrm{a}}$ & $37.7^{\mathrm{a}}$ \\
\hline & TsdOm & $34.8^{\mathrm{c}}$ & $4.7^{\mathrm{c}}$ & $6.3^{\mathrm{a}}$ & $59.5^{\mathrm{a}}$ & $32.3^{\mathrm{a}}$ \\
\hline & IBA-4000ppm & $28.3^{\mathrm{d}}$ & $11.2^{\mathrm{c}}$ & $6.1^{\mathrm{d}}$ & $46.2^{\mathrm{b}}$ & $24.1^{\mathrm{b}}$ \\
\hline & IBA-8000ppm & $38.9^{\mathrm{b}}$ & $6.5^{\mathrm{c}}$ & $4.2^{\mathrm{c}}$ & $51.5^{\mathrm{d}}$ & $47.2^{\mathrm{b}}$ \\
\hline & TsaOm+ IBA-8000ppm & $35.9^{f}$ & $12.7^{\mathrm{d}}$ & $6.3^{\mathrm{ei}}$ & $50.3^{c}$ & $24.9^{\mathrm{ci}}$ \\
\hline & TsaOm+ IBA-4000ppm & $46.7^{g}$ & $13.9^{\mathrm{de}}$ & $7.3^{\mathrm{fi}}$ & $56.6^{\mathrm{ce}}$ & $39.5^{\mathrm{dj}}$ \\
\hline & TsdOm+ IBA-4000ppm & $45.1^{\mathrm{g}}$ & $14.7^{\mathrm{de}}$ & $10.2^{\mathrm{bi}}$ & $46.5^{\mathrm{b}}$ & $52.4^{\mathrm{ek}}$ \\
\hline & TsdOm+ IBA-8000ppm & $17.1^{\mathrm{i}}$ & $19.5^{\mathrm{e}}$ & $10.9^{\mathrm{bi}}$ & $54.6^{\mathrm{c}}$ & $15.3^{\mathrm{fl}}$ \\
\hline \multirow[t]{9}{*}{ M106 } & Control & $19.4^{\mathrm{a}}$ & $15.4^{\mathrm{a}}$ & $11.8^{\mathrm{a}}$ & $32.2^{\mathrm{a}}$ & $29.6^{\mathrm{a}}$ \\
\hline & TsaOm & $21.9^{\mathrm{a}}$ & $15.5^{\mathrm{ac}}$ & $13.3^{\text {bf }}$ & $30.7^{\mathrm{a}}$ & $41.5^{b}$ \\
\hline & TsdOm & $14.8^{b}$ & $20.3^{\mathrm{dc}}$ & $14.3^{\mathrm{cf}}$ & $35.2^{\mathrm{a}}$ & $28.3^{\mathrm{a}}$ \\
\hline & IBA-4000ppm & $21.7^{\mathrm{a}}$ & $17.9^{\mathrm{ac}}$ & $9.9^{\mathrm{dg}}$ & $29.1^{\mathrm{a}}$ & $45.5^{\mathrm{b}}$ \\
\hline & IBA-8000ppm & $8.4^{\mathrm{c}}$ & $19.4^{\mathrm{ac}}$ & $9.8^{\mathrm{ag}}$ & $31.1^{\mathrm{a}}$ & $25.0^{\mathrm{a}}$ \\
\hline & TsaOm+ IBA-4000ppm & $12.9^{\mathrm{b}}$ & $19.5^{\mathrm{bc}}$ & $11.9^{\text {ah }}$ & $34.3^{\mathrm{a}}$ & $20.2^{\mathrm{c}}$ \\
\hline & TsaOm+ IBA-8000ppm & $28.1^{\mathrm{e}}$ & $22.3^{\mathrm{dc}}$ & $11.4^{\mathrm{ah}}$ & $29.4^{\mathrm{a}}$ & $38.3^{\mathrm{b}}$ \\
\hline & TsdOm+ IBA-4000ppm & $8.3^{\mathrm{c}}$ & $18.8^{\mathrm{ac}}$ & $11.3^{\mathrm{ah}}$ & $27.7^{\mathrm{a}}$ & $20.0^{c}$ \\
\hline & TsdOm+ IBA-8000ppm & $27.9^{\mathrm{e}}$ & $19.4^{\mathrm{bc}}$ & $10.1^{\mathrm{ei}}$ & $27.4^{\mathrm{a}}$ & $51.7^{\mathrm{d}}$ \\
\hline \multirow[t]{9}{*}{ M109 } & Control & $28.4^{\mathrm{a}}$ & $6.9^{\mathrm{a}}$ & $9.8^{\mathrm{a}}$ & $17.3^{\mathrm{a}}$ & $17.4^{\mathrm{a}}$ \\
\hline & TsaOm & $25.8^{\mathrm{a}}$ & $14.2^{\mathrm{b}}$ & $12.8^{\mathrm{ab}}$ & $30.7^{\mathrm{b}}$ & $45.1^{\mathrm{b}}$ \\
\hline & TsdOm & $37.4^{\mathrm{b}}$ & $9.7^{\mathrm{a}}$ & $8.8^{\mathrm{ac}}$ & $17.8^{\mathrm{a}}$ & $32.6^{c}$ \\
\hline & IBA-4000ppm & $39.1^{b}$ & $12.5^{\mathrm{b}}$ & $8.2^{\mathrm{ac}}$ & $15.0^{\mathrm{a}}$ & $33.5^{\mathrm{c}}$ \\
\hline & IBA-8000ppm & $41.2^{\mathrm{b}}$ & $9.8^{\mathrm{a}}$ & $8.9^{\mathrm{ac}}$ & $18.4^{\mathrm{a}}$ & $49.5^{\mathrm{b}}$ \\
\hline & TsaOm+ IBA-4000ppm & $21.1^{\mathrm{c}}$ & $11.4^{\mathrm{a}}$ & $7.7^{\mathrm{ac}}$ & $19.2^{\mathrm{a}}$ & $30.4^{\mathrm{c}}$ \\
\hline & TsaOm+ IBA-8000ppm & $19.5^{\mathrm{c}}$ & $12.2^{\mathrm{b}}$ & $11.4^{\mathrm{ab}}$ & $18.4^{\mathrm{a}}$ & $24.5^{\mathrm{d}}$ \\
\hline & TsdOm+ IBA-4000ppm & $30.6^{\mathrm{a}}$ & $8.3^{\mathrm{a}}$ & $8.7^{\mathrm{ac}}$ & $18.3^{\mathrm{a}}$ & $33.3^{\mathrm{c}}$ \\
\hline & TsdOm+ IBA-8000ppm & $40.5^{\mathrm{b}}$ & $10.3^{\mathrm{a}}$ & $8.9^{\mathrm{ac}}$ & $23.0^{\mathrm{c}}$ & $34.1^{\mathrm{c}}$ \\
\hline \multirow[t]{9}{*}{ MM793 } & Control & $6.0^{\mathrm{a}}$ & $7.0^{\mathrm{a}}$ & $6.5^{\mathrm{a}}$ & $35.3^{\mathrm{a}}$ & $13.8^{\mathrm{a}}$ \\
\hline & $\mathrm{TsaOm}$ & $15.2^{\mathrm{b}}$ & $4.6^{\mathrm{bc}}$ & $7.8^{\mathrm{ab}}$ & $38.3^{\mathrm{a}}$ & $37.5^{\mathrm{b}}$ \\
\hline & TsdOm & $13.0^{\mathrm{c}}$ & $3.7^{\mathrm{b}}$ & $4.8^{\mathrm{ac}}$ & $31.7^{\mathrm{a}}$ & $27.8^{\mathrm{c}}$ \\
\hline & IBA-4000ppm & $10.9^{\mathrm{d}}$ & $7.8^{\mathrm{a}}$ & $5.6^{\mathrm{ac}}$ & $27.6^{\mathrm{a}}$ & $34.5^{\mathrm{b}}$ \\
\hline & IBA-8000ppm & $11.5^{\mathrm{d}}$ & $6.7^{\mathrm{ac}}$ & $4.1^{\mathrm{ac}}$ & $26.1^{\mathrm{ab}}$ & $51.7^{\mathrm{d}}$ \\
\hline & TsaOm+ IBA-4000ppm & $16.3^{\mathrm{b}}$ & $8.7^{\mathrm{a}}$ & $5.2^{\mathrm{a}}$ & $34.2^{\mathrm{a}}$ & $33.3^{\mathrm{c}}$ \\
\hline & TsaOm+ IBA-8000ppm & $16.4^{\mathrm{b}}$ & $5.0^{\mathrm{c}}$ & $4.2^{\mathrm{ac}}$ & $23.9^{\mathrm{ab}}$ & $29.2^{\mathrm{b}}$ \\
\hline & TsdOm+ IBA-4000ppm & $16.0^{\mathrm{b}}$ & $6.1^{\mathrm{ac}}$ & $4.3^{\mathrm{ac}}$ & $30.9^{\mathrm{a}}$ & $42.6^{\mathrm{bd}}$ \\
\hline & TsdOm+ IBA-8000ppm & $14.4^{\mathrm{c}}$ & $7.8^{\mathrm{a}}$ & $4.8^{\mathrm{ac}}$ & $24.1^{\mathrm{ab}}$ & $29.6^{\mathrm{b}}$ \\
\hline
\end{tabular}

Control = Site soil; IBA = Indole-3-butyric acid (4000ppm and 8000ppm); Bf = Bitten felder rootstock; M106, M109, MM793 = clonal apple rootstocks; OSM = Organic substrate mixture; TsaOm = Top forest soil+ sand+ organic manure; TsdOm = Top forest soil+ sawdust+ organic manure. ${ }^{*}$ Mean values with same letters in the same column and for a particular variety are not significantly different at 5\% using average LSD 
The effect of IBA on rooting percentage was not significant $(\mathrm{P}>0.05)$ across all the apple rootstocks (Table 2). However, the use of IBA-4000 ppm increased rooting from 19.4 to $21.7 \%$ in M106, 28.4 to $39.1 \%$ in M109 and 6 to $10.9 \%$ in MM793 (Table 3). Both IBA-4000 and IBA-8000 ppm reduced rooting percentages in bitten felder to 28.3 and $38.9 \%$ respectively compared to $46.3 \%$ under control conditions. Surprisingly, the highest rooting percentage $(46.7 \%)$ was recorded in bitten felder treated with combination of TsaOm and IBA-4000 ppm but individual treatments with TsaOm resulted in lower rooting percentages at $37.1 \%$ while $\mathrm{TsdOm}$ reduced rooting percentages to $34.8 \%$ compared to $46.3 \%$ under control (site soil) conditions (Table 3).

The variety, OSM, and IBA interactions also had significant $(\mathrm{P}<0.001)$ effect on the rooting percentages of apple rootstocks (Table 2). The TsdOm+ IBA-8000ppm interaction effects resulted in higher rooting percentages in three rootstock varieties viz., M106, M109 and MM793 while TsdOm+ IBA-4000ppm increased rooting percentages in M109 and MM793. The highest rooting percentage due to interaction effects was $40.5 \%$ obtained in M109 treated with TsdOm+ IBA-8000ppm.
The interaction between TsaOm and IBA (TsaOm+ IBA-4000ppm and TsaOm+ IBA$8000 \mathrm{ppm}$ ) only significantly increased rooting percentages in MM793 (Table 3). Figure 2 provides evidence of profuse rooting that was obtained as a result of using OSM and IBA to propagate apple rootstocks under trench layering.

Effect of OSM and IBA on root numbers and root Lengths. Both IBA and OSM had significant $(\mathrm{P}<0.01)$ effect on root numbers in all the four apple rootstock varieties (Table 2 ). The highest number of roots (23.1) was recorded in bitten felder treated with TsaOm; while the lowest root number (3.7) was obtained in MM793 followed by 4.7 in bitten felder both under TsdOm (Table 3). However, TsdOm had a positive effect on root numbers posting 20.3 and 9.7 in M106 and M109, respectively. Increasing the concentration of IBA from 4000ppm to $8000 \mathrm{ppm}$ resulted in inconsistent inhibitory effect on the number of roots causing a reduction from 11.2 to 6.5 (Table 3). The variety, OSM and IBA interaction effects had significant $(\mathrm{P}<0.01)$ positive effects on root numbers in all rootstocks except in MM793 where TsaOm+

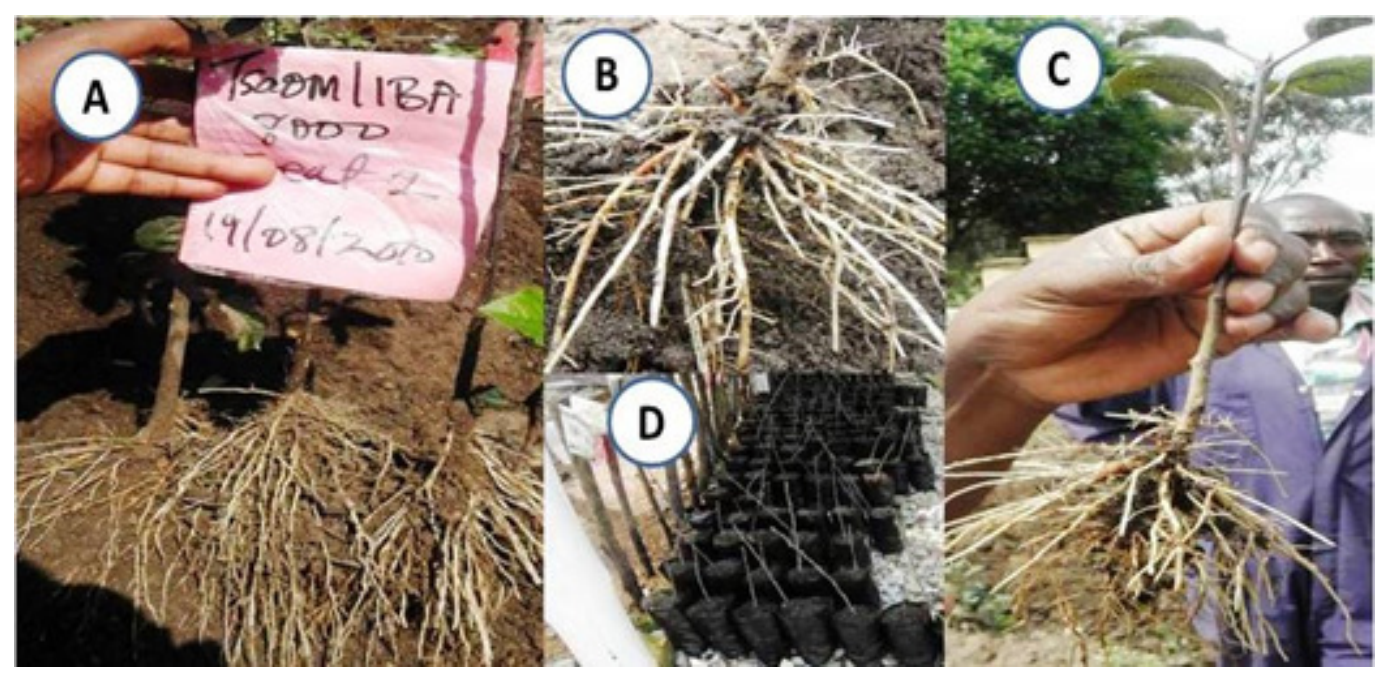

Figure 2. Profuse rooting of apple rootstocks (A and B), harvested rootstock for assessment of root characteristics (C) and potted rootstocks in the acclimatisation nursery (D) at Bugongi-KAZARDI in South-Western Uganda. 
IBA-8000ppm and TsdOm+ IBA-8000ppm resulted in lower root numbers compared to the control conditions (Table 3).

Similarly, root length varied significantly $(\mathrm{P}<0.01)$ with the concentration of IBA and the type of OSM across the four apple rootstocks (Table 2). The highest root length $(14.9 \mathrm{~cm})$ was recorded in bitten felder treated with TsaOm; while the shortest $(4.1 \mathrm{~cm})$ was in MM793 when treated with IBA-8000 ppm. There were substantial increases in root lengths of all the four rootstocks when treated with TsaOm but the alternative OSM (TsdOm) resulted in reduced root length in all rootstocks except in M106. Both IBA-4000 and IBA-8000 ppm negatively affected root lengths across the four apple rootstocks compared to the control and the interaction effects between OSM and IBA resulted in reduced root lengths despite being significant in Table 1.

Effect of OSM and IBA on sprout length and survivability. There were significant $(\mathrm{P}<0.01)$ effects of OSM on sprout length but non-significant on the survival rates of apple rootstocks. The effect of IBA was significant $(\mathrm{P}<0.01)$ for both sprout length and survival rates of apple rootstocks (Table 2). Generally, sprout length were high; ranging from a minimum of $15.0 \mathrm{~cm}$ in $\mathrm{M} 109$ when treated with IBA-4000 $\mathrm{ppm}$ to the maximum sprout length of $56.6 \mathrm{~cm}$ observed in bitten felder treated with a combination of TsaOm + IBA$4000 \mathrm{ppm}$ (Table 3). The use of OSM viz., TsaOm increased sprout lengths in bitten felder $(56.2 \mathrm{~cm}), \mathrm{M} 109(30.7 \mathrm{~cm})$ and MM793 (38.3 $\mathrm{cm}$ ); while TsdOm increased sprout length in all rootstocks except MM793. In M106, the highest sprout length $(35.2 \mathrm{~cm})$ was recorded under TsdOm; while the lowest $(27.4 \mathrm{~cm})$ was recorded under combined treatment of TsdOm + IBA-8000 ppm but TsdOm + IBA-4000 ppm increased sprout length to $34.3 \mathrm{~cm}$ (Table 3 ). Hormone treatments with IBA-4000 ppm and IBA-8000 ppm had an inhibitory effect on elongation of sprouts resulting in shorter sprouts compared to the control except IBA-
8000 ppm on M109 where sprout length increased marginally from 17.3 in control to $17.8 \mathrm{~cm}$. The interaction between OSM and IBA increased sprout length in M109 with the highest effect recorded for TsdOm+ IBA$8000 \mathrm{ppm}$ at $23.0 \mathrm{~cm}$.

Survival rates varied significantly across treatments and interaction effects (Table 2). Significant effects were observed for IBA $(\mathrm{P}<0.01)$, Variety + IBA $(\mathrm{P}<0.01)$, and IBA + OSM $(p<0.001)$ interactions. Survival rates of apple rootstocks increased with both TsaOm and TsdOm treatments except in M106 where TsdOm reduced survivability from $29.6 \%$ under control conditions to $28.3 \%$ (Table 3 ). High survival rates were obtained under IBA8000 ppm in MM793 and M109 at 51.7 and $49.5 \%$, respectively while the survival rate in bitten felder was $52.4 \%$ under TsdOm + IBA4000 ppm. Moreover, TsdOm + IBA-8000 ppm interaction increased survival rates of M106 from 29.6\% under control conditions to $51.7 \%$ which was the highest survivability recorded for M106 (Table 3).

Survival of apple rootstocks at acclimatisation stage. Logistic regression analysis revealed that rooting significantly influenced $(\mathrm{P}<0.01)$ the survival of apple rootstocks propagated under trench layering with IBA and OSM (Table 4). The odds ratios indicated that for every one-unit increase in rooting percentage, there was a corresponding $1.4 \%$ increase in the survivability of the apple rootstocks. Similarly, sprout length had significant $(\mathrm{P}<0.01)$ effect on the survivability of the apple rootstocks, with the odds suggesting that a unit change in sprout length results in a $20 \%$ increase in the survivability of apple rootstocks (Table 4).

Conversely, root length negatively influenced the survival of apple rootstocks given the odds ratio of less than unity (0.971) and a negative coefficient of -0.029 (Table 4); while IBA-4000 ppm significantly $(\mathrm{P}<0.01)$ increased survivability of apple rootstocks by $33.1 \%$ (odds of 2.331) compared to the 
TABLE 4. Logistic regression analysis for the effect of rooting, root numbers, root length, IBA and OSM on survivability of apple rootstocks propagated by trench layering at Bugongi-KAZARDI, South-Western Uganda

\begin{tabular}{lrrr}
\hline Factors & Coefficient $\pm \mathrm{se}$ & Odds ratio & Sig. (P value) \\
\hline Number of roots & $0.006 \pm 0.012$ & 1.006 & $0.614 \mathrm{~ns}$ \\
Rooting & $0.700 \pm 0.387$ & 2.014 & $0.071^{*}$ \\
Sprout length & $0.020 \pm 0.007$ & 1.02 & $0.002^{* *}$ \\
Root length & $-0.029 \pm 0.024$ & 0.971 & \\
Organic substrate mixtures (OSM) & & & \\
& & & $0.216 \mathrm{~ns}$ \\
TsaOm & $0.017 \pm 0.270$ & 1.017 & $0.521 \mathrm{~ns}$ \\
TsdOm & $0.180 \pm 0.280$ & 1.197 & \\
Hormone concentration (ppm) & & & \\
& & & $0.005^{* *}$ \\
IBA-4000 ppm & $0.846 \pm 0.299$ & 2.331 & $0.79 \mathrm{~ns}$ \\
IBA-8000 ppm & $0.068 \pm 0.254$ & 1.07 & $0.041^{*}$ \\
Constant & $0.92 \pm 0.450$ & & $0.002^{*}$ \\
Model chi square & -321.522 & & \\
Log likelihood & 1.39 & & \\
Multicollineartiy ( mean VIF ) & & & \\
\hline
\end{tabular}

$*$, ** = significant at $\mathrm{P}<0.05$ and $\mathrm{P}<0.01$ respectively; $\mathrm{ns}=$ non-significant; Sig. = significance level

control. The OSM (TsaOm) resulted in $1.7 \%$ increase in survivability while OSM (TsdOm) showed a $1.97 \%$ increase in the survivability of apple rootstocks than under control conditions.

\section{DISCUSSION}

Variability of root, sprout and survival characteristics. The significant $(\mathrm{P}<0.01)$ variability among the four apple rootstocks in response to OSM and IBA treatments (Table 2 ), suggests potential for selection and production of quality apple seedlings. Differences in rooting characteristics among the rootstock genotypes might be due to variation in endogenous auxin levels and the inherent genetic characteristics of genotypes. The bitten felder rootstocks were developed from seed imports from Germany; while M106, M109 and MM793 are clonal rootstocks imported from South Africa (Turyomurugyendo et al., 2004; Agaba, 2011); this could explain the observed differences between the different varieties (Table 2 and Table 3). The significant interaction between apple rootstock variety and OSM for rooting percentage and root numbers (Table 2) suggests variability in the response of apple rootstock genotypes to OSM and IBA concentrations compared to individual treatments.

Effect of OSM on root characteristics. The results revealed that organic substrate mixtures (OSM) increased the rates of rooting, root numbers and root length of apple rootstocks propagated by trench layering (Table 3 ). Both root numbers and root length increased perhaps because of improved soil structure, water holding capacity, drainage, and aeration which enhances gaseous exchange between roots and the atmosphere thus promoting adventitious root growth.

The use of organic substrate mixtures has been reported in propagation studies of several rootstocks with positive effects on rooting, shooting, and survival (Galavi et al., 2013; 
Shabani et al., 2015; Ari, 2016). According to Nia et al. (2015), culture media involving manure, soil, peat, tea wastes and rice husks have significant effects on cation exchange capacity and soil $\mathrm{pH}$, aeration and water retention capacity of soils which improves the absorption of nutritional elements. Organic substrate mixtures serves as a reservoir for nutrients, provide anchorage for rootstock roots and modifies soil texture leading to improved nutrient availability and nutrient flow and enhanced absorption by the roots.

According to Yaseen et al. (2009), organic substrates enhance availability of metabolic substrates which support the high-energy processes of root initiation and growth. However, both organic substrate mixtures (TsaOm and TsdOm) in this study resulted in lower rooting percentages in bitten felder compared to the control (site soil) (Table 3). This suggests that root initiation and growth in bitten felder could have been negatively affected by water soluble phenolic compounds found in organic substrate mixtures. This argument is supported by $\mathrm{Ma}$ and Nichols (2004), who reported that organic substrates contain phytotoxic compounds, high cellulose and lignin contents and insufficient nitrogen supplies which could severely restrict root initiation and growth.

Effect of IBA on the rooting characteristics of apple rootstocks. The current results revealed that IBA treatment increased root length, sprout length and survival of rootstocks (Table 3 ). The ability of synthetic auxins such as IBA to promote rooting during propagation of fruit trees such as apples is widely reported (Doric et al., 2014; Sharma et al., 2007; Khatik and Sharma, 2013). Krieken et al. (1993) while studying the root regeneration of stem slices of apple shoots; observed that application of exogenous IBA enhances rooting through increased internalfree IBA, which synergistically modifies synthesis and action of endogenous IAA and enhances tissue sensitivity to endorgenous IAA. However, the usage and effects of IBA in trench layering is rare in literature, save for stool layering where IBA was reported to promote the rooting potentiality of apple clonal rootstock Merton 793 (Khatik and Sharma, 2013).

In the present study, the positive effect of IBA on rooting, root length and survival of apple rootstocks might have been enhanced by wounding/girdling of the sprouts at the root collar and applying IBA to the girdle. These results corroborate findings of Taiz and Zeiger (2002) who reported that rooting can be enhanced in a layering system, by girdling or wounding the stem to cause accumulation of carbohydrates and auxins above the girdled area, as the downward movements of these compounds are blocked by the girdle. According to Hartmann et al. (1997), the girdling of the sclerenchyma/lignified tissue enhance absorption of the applied plant growth regulators and stimulate root initiation.

The results further revealed that IBA- 4000 ppm gave the highest rooting response in M793, M106 and M109 apple rootstocks. Such high hormone concentrations are recommended for propagating hard-to-root species such as apples (Srivastava et al., 2006). Khatik and Sharma (2013) reported IBA-2500 ppm as the best treatment for inducing better root system in apple clonal rootstock-Merton 793, in terms of rooting percentage, number of roots, total root length and root to shoot ratio. So IBA-4000ppm can be considered optimum for propagation of apple rootstocks under trench layering that gives the best rooting and survival characteristics.

Combined effect of IBA and OSM on root characteristics. The combination of IBA and OSM resulted in significant increase in the number of roots, root length, and rooting percentage (Table 3). These results suggest that combined use of OSM and IBA stimulates root initiation better than when single treatment of either OSM or IBA was used. This is illustrated by results of the highest rooting percentages in bitten felder (46.7\%), M106 
(28.1\%), and MM93 (16.4\%) all obtained under combined treatments with TsaOm + IBA-4000ppm, TsaOm + IBA-8000 and TsaOm + IBA-8000 ppm, respectively (Table 3). This indicates that mixing OSM and IBA has positive effects on rooting characteristics of apple rootstocks propagated by trench layering.

Similar observations were reported by Ercisli et al. (2002) while studying the propagation of kiwifruit which indicate that the combined effects of IBA concentrations, cutting time and rooting media significantly influenced rooting percentage, root length and root numbers of hardwood cuttings better than any single treatment.

Survivability of rootstocks at acclimatisation. Logistic regression results (Table 4) showed that rooting influenced survivability of the layers regardless of the number of roots on the sprouts. Rooting is one of the most critical steps in propagation of apple rootstocks and Sharma et al. (2007) reported that consistent high frequency rooting of apple is more difficult to achieve and that a high percentage of rooted shoots and a high quality root system are necessary for survival during acclimatisation.

The results further revealed that sprout length significantly influenced survivability of the rootstocks. This means that the longer the stem of the sprout, the higher the chances of continued food supply since the stem plays an important role in the storage and translocation of water and mineral nutrients to other parts of the rootstock.

Significant effect of IBA-4000 ppm on survivability of apple root stocks (Table 4); indicates that IBA-4000 ppm might be the approximate optimum concentration for the best survival rates of apple rootstocks propagated by trench layering. Increasing hormone concentration from IBA-4000 ppm to IBA-8000 ppm significantly $(\mathrm{P}<0.01)$ reduced root length and sprout length and the survival of the apple rootstocks. Similar findings were reported by Sharma et al. (2007) that IBA stimulates the formation of roots in M7 and MM106 but high dosage of IBA delays root and shoot development which results in poor survival of propagated apple rootstocks. This result is corroborated by findings of Hasnat et al. (2007), which indicated that growth and elongation of roots and sprouts in apple rootstocks are promoted by auxins (IBA) at low concentrations; while high IBA concentrations tend to curtail growth due to synthesis of endogenous ethylene.

The highest odds ratio for survivability of the propagated rootstocks were obtained under IBA-4000 ppm indicating that this concentration is appropriate for optimum rooting, sprout length and survival of apple rootstocks at acclimatisation stage of trench layering.

\section{CONCLUSION}

The results generally indicate that using IBA both at 4000 and $8000 \mathrm{ppm}$, and the OSM (TsaOm and TsdOm) promoted rooting, root numbers, root length, sprout length and survival of apple rootstocks in various ways enhancing potentiality for rapid propagation under trench layering. The combination of organic substrate mixtures and IBA enhances rapid propagation of apple rootstocks under trench layering. TsaOm is the best OSM for enhanced trench layering of apple rootstocks, bitten felder, M109 and MM793 giving the highest number of roots and longest root length while TsdOm is the best substrate for propagation of M106. Rooting, sprout length and IBA $4000 \mathrm{ppm}$ significantly improves survivability of apple rootstocks during acclimatisation.

\section{ACKNOWLEDGMENT}

The authors acknowledge Kachekano Zonal Agricultural Research and Development Institute (KAZARDI) for a trench layering nurseries and apple germplasm. This research was funded by the Carnegie Institutional 
Development Programme grant through the Directorate of Research and Graduate Training, Makerere University. Regional Universities Forum for Capacity Building in Agriculture (RUFORUM) supported the preparation and publication of this manuscript under the grant, "Training the next generation of scientists" from Carnegie Cooperation of New York.

\section{REFERENCES}

Agaba, R. 2011. Trench layering technologies for rapid multiplication of elite apple germplasm (Malus domestica) in Kabale Highlands, Western Uganda. Msc. Thesis, Makerere University, Kampala, Uganda. http://makir.mak.ac.ug/handle/10570/ 1989?show=full. $51 \mathrm{pp}$.

Akbari, M., Maejima, T., Otagaki, S., Shiratake, K. and Matsumoto, S. 2015. Efficient rooting system for apple M9 rootstock using rice seed coat and smocked rice seed coat. International Journal of Agronomy 1:1-4. http://dx.doi.org/10.1155/ 2015/107906

Ari, E. 2016. Effects of different substrates and IBA concentrations on adventitious rooting of native Vitex agnus-castus L. cuttings. Acta Scientiarum Polonorum. Hortorum Cultus 15(2):27-41.

Chemining'wa, G., Mulagoli, I., Mwonga, S., Ndubi, J., Tum, J. and Turyamureeba, G. 2005. A study to develop strategies to exploit market opportunities for apple farmers in Kabale, Uganda. Working Document Series 125. http://www.icraedu.org/objects/public_eng/ACFRU khMi.pdf.

Cornille, A., Giraud, T., Smulders, M.J.M., Roldán-Ruiz, I. and Gladieux, P. 2014. The domestication and evolutionary ecology of apples. Trends in Genetics 30(2):57-65.

Crabtree, S.B. 2004. Sexual and asexual reproductive characteristics of the North American pawpaw [Asimina triloba (L.) Dunal. Msc Thesis. University of
Kentucky, Lexington, Kentucky, United States of America. https://uknowledge.uky. edu/gradschool theses/409.

Doric, D., Ognjanov, V., Ljubojevic, M., Barac, G., Dulic, J., Pranjic, A. and Dugalic, K. 2014. Rapid propagation of sweet and sour cherry rootstocks. Notulae Botanicae Horti Agrobotanici Cluj-Napoca 42(2): 488-494. DOI: 10.15835/nbha.42.2.9671.

Ercisli, S., Anapali, Ö., Esitken, A. and Sahin, Ü. 2002. The effects of IBA, rooting media and cutting collection time on rooting of Kiwifruit. Gartenbauwissenschaft 67(1): 34-38.

Galavi, M., Karimian, M. A. and Mousavi, S.R. 2013. Effects of different auxin (IBA) concentrations and planting-beds on rooting grape cuttings (Vitis vinifera). Annual Review and Research in Biology 3(4):517523.

Griesbach, J. 2007. Growing temperate fruit trees in Kenya. World Agroforestry Centre (ICRAF). Ouya, E.L.S.D., Simons, A.J. and Beniest, J. (Eds.). SciTech Publishers (Kenya) Ltd. Nairobi, Kenya. 128pp.

Hartmann, H.T., Kester, D.E., Davis, J. and Geneve, R.L. 1997. Plant propagation: Principles and practices, Prentice-Hall, Upper Saddle River, New Jersey. Northeastern, USA.

Hasnat, R., Abbasi, N.A., Ahmad, T. and Hafiz, I.A. 2007. Induction and regeneration of hypocotyls derived calli in hot chilli (Capsicum frutescens L.) varieties. Pakistan Journal of Botany 39: 1787-1795.

ICRAF. 2003. Temperate fruits go tropical: apples, peaches, pears and plums take to the hills of Uganda. ICRAF: Nairobi, Kenya.

Kashyap, R. and Guleria, A. 2015. Socioeconomic and marketing analysis of apple growers in Mandi district of Himachal Pradesh. Journal of Hill Agriculture 6(2): 202-206.

Katuuramu, D.N. 2012. Evaluation of rootstock and crop load effects on the performance of Gibson Golden Delicious' and three scab-resistant apple cultivars. 
MSc Thesis, Iowa State University, USA. http://lib.dr.iastate.edu/etd/12576 68pp.

Khatik, P. and Sharma, D. 2013. Effect of IBA and NAA on stool layering in apple clonal rootstock Merton 793. Progressive Horticulture 45(2):388-391.

Krieken, W.M., Breteler, H., Visser, M.H. and Mavridou, D. 1993. The role of the conversion of IBA into IAA on root regeneration in apple: Introduction of a test system. Plant Cell Reports 12(4): 203-206.

Liu, X., Ren, J., Zhu, Y., Han, W., Xuan, H. and Ge, L. 2016. The preservation effect of ascorbic acid and calcium chloride modified chitosan coating on fresh-cut apples at room temperature. Colloids and Surfaces A: Physicochemical and Engineering Aspects 502: 102-106.

Ma, Y.B. and Nichols, D.G. 2004. Phytotoxicity and detoxification of fresh coir dust and coconut shell. Communications in Soil Science and Plant Analysis 35(12):205218.

Musana, S.T., Rausesen, T.J. and Esegu, F.O. 2006. Fruit tree production. In: Namirembe, S. (Ed.). Agroforestry for development in Uganda. ANAFE Secretariat.

Namirembe, S., Obua, J., Nyeko, P., Ndemere, P. and Tumwebaze, S. 2006. Agroforestry for development in Uganda: A synthesis of topics discussed at the $2^{\text {nd }}$ National Agroforestry Workshop, September 2001, ICRAF. Nairobi, Kenya. 133pp.

Nia, A.F., Sardrodi, A.F., Habibi, M.M. and Bahman, S. 2015. Morphological and physiological changes of aloe (Aloe barbadensis Miller.) in response to culture media. International Journal of Agronomy and Agricultural Research 6(6): 100-105.

Noormohammadi, Z., Fazeli, S., Sheidai, M. and Farahani, F. 2015. Molecular and genome size analyses of somaclonal variation in apple rootstocks Malling 7 and Malling 9. Acta Biologica Szegediensis 59(2):139-149.

Ntakyo, P., Mugisha, J. and Elepu, G. 2013. Socio-economic factors affecting apple production in South-western Uganda. African Crop Science Journal 21(4):311 321.

Raussen, T. 2001. Deciduous fruit tree for Uganda's highlands. In series: Useful trees for farming. Technical Bulletin, No. 2. International Centre for Research in Agroforestry (ICRAF), Kabale, Uganda. http://outputs.worldagroforestry.org/cgibin/koha/opac-detail.pl?biblionumber $=38749$. $23 \mathrm{pp}$.

Shabani, Z., Moghadam, E.G., Abedi, B. and Tehranifar, A. 2015. Effect of media and regulators of plant growth on micro propagation of Myrobalan 29C rootstock. Journal of Horticulture and Forestry 7(3):57-64.

Sharma, T., Modgil, M. and Thakur, M. 2007. Factors affecting induction and development of in vitro rooting in apple rootstocks. Indian Journal of Experimental Biology 45(9):824-829.

Sharma, Y., Singh, S.K. and Thakur, N. 2013. Clonal propagation in apple. International Journal of Agricultural Sciences 9(1):423428.

Srivastava, K.K., Bhat, K.M., Sharma, M.K. and Nazki, I.T. 2006. Studies on multiplication of M106 rootstock of apple through trench layering in Kashmir valley. Research on Crops 7(1):311-312.

Taiz, L. and Zeiger, E. 2002. Plant Physiology. Sinauer Associates, Inc., Sunderland, Sunderland, Massachusetts, USA. 690pp. Turyomurugyendo, L.K., Boffa, J.M. and Hakiza, J.J. 2004. Introduction of deciduous fruit tree growing in the tropical high lands of Kabale, Uganda. Uganda Journal of Agriculture Sciences (9):470480.

Yaseen, M., Ahmad, T., Abbasi, N.A. and Hafiz, I.A. 2009. Assessment of apple rootstocks M 9 and M 26 for in vitro rooting potential using different carbon sources. Pakistan Journal of Botany 41(2): 769-781. 